${ }^{4}$ Frantz, A G, Kleinberg, D L, and Noel, G L, Recent Progress in Hormone Research, 1972, 28, 527.

5 McNeilly, A S, fournal of Biosocial Science, 1977, suppl No 4, p 5.

${ }^{6}$ Cobo, E, et al, American fournal of Obstetrics and Gynecology, 1967, 97, 519.

7 Caldeyro-Barcia, $\mathrm{R}$, in Lactogenesis: The Initiation of Milk Secretion at Parturition, ed M Reynolds and S J Folley, p 229. Philadelphia, University of Pennsylvania Press, 1969.

8 Vorherr, H, in The Breast: Morphology, Physiology and Lactation. New York, Academic Press, 1974.

${ }^{9} \mathrm{Fox}, \mathrm{C}$ A, and Knaggs, G S, fournal of Endocrinology, 1969, 45, 145.

10 Cobo, E, in Lactogenic Hormones, Fetal Nutrition and Lactation, ed J B Josimovich, M Reynolds, and E Cobo, p 433. New York, John Wiley and Sons, 1974.
11 Newton, N, and Newton, M, fournal of Pediatrics, 1948, 33, 698.

12 Newton, N, and Newton, M, Pediatrics, 1950, 5, 726.

13 Lincoln, D W, Hill, A, and Wakerley, J B, fournal of Endocrinology, 1973, $57,459$.

${ }^{14}$ Midgley, A R, jun, and Jaffe, R B, fournal of Clinical Endocrinology and Metabolism, 1971, 33, 962.

15 Short, R V, Proceedings of the Royal Society, Series B, 1976, 195, 3.

16 May, R M, Nature, 1978, 272, 491.

17 Aono, T, et al, fournal of Clinical Endocrinology and Metabolism, 1977, 44, 1101

${ }^{18}$ Delvoye, P, et al, Clinical Endocrinology, 1977, 7, 257.

(Accepted 2 Fune 1978)

\title{
Measurement of capillary blood glucose in filter-paper spots: an aid to the assessment of diabetic control
}

\author{
K WAKELIN, D J GOLDIE, M HARTOG, A P ROBINSON
}

British Medical fournal, 1978, 2, 468-469

\section{Summary and conclusions}

A method of measuring glucose in capillary blood spotted on to filter paper was evaluated. Between-batch reproducibility was about $6 \%$, and the glucose remained stable in the spots for up to four days. Adoption of the method should improve control of diabetes, particularly insulin-dependent forms.

\section{Introduction}

The importance of close control of diabetes in reducing the incidence of complications is now widely accepted ${ }^{1}$ and has led to a re-examination of methods used for assessing control. Although many metabolic abnormalities are found in diabetics, tests reflecting blood glucose concentrations are still the most useful indicators of control. ${ }^{2}$ Traditionally the degree of hyperglycaemia has been assessed indirectly by semi-quantitative measurement of sugar in the urine. This is not sensitive enough, however, as glycosuria usually appears only when blood glucose values are very high. The concentration of circulating glycosylated haemoglobin may provide the best overall guide to the quality of diabetic control, ${ }^{3}$ but the day-to-day monitoring of insulin requirements would probably be best achieved by serial blood sugar determinations performed on patients during their normal daily activities. In some clinics patients take such samples themselves by finger-prick into tubes containing dried anticoagulant and fluoride for later glucose determination in the laboratory. We have not been successful with this approach, as most capillary blood samples clotted and were unsuitable for analysis. Sönksen et $a l^{4}$ and Walford $e t a l^{5}$ reported their experiences of self-monitoring of capillary blood glucose by

\footnotetext{
Department of Clinical Chemistry, Southmead Hospital, Bristol BS10 5NB

$\mathrm{K}$ WAKELIN, MB, CHB, registrar in pathology

D J GOLDIE, MD, MRCPATH, consultant chemical pathologist

University Department of Medicine, Southmead Hospital, Bristol BS10 5NB

M HARTOG, DM, FRCP, reader in medicine

A P ROBINSON, BSC, MRCP, medical registrar
}

patients using either Dextrostix or Reflotest strips and reading $\vec{N}$ them on Eyetone and Reflomat meters respectively. The merits of this approach are discussed below.

We have explored the possibility of measuring glucose in capillary blood samples spotted on to filter paper, dried, and subsequently eluted in the first stage of the assay. Such an approach was suggested in 1961,6 and several techniques have been described ${ }^{6-8}$; so far as we know, however, they are not widely used. We decided to investigate this approach again using, in particular, a common micro-glucose-oxidase method ${ }^{9}$ that is used routinely in our laboratory for paediatric investigations.

\section{Materials and methods}

Patients in general medical wards were asked to provide capillary blood samples by finger-prick using sterile lancets (Lance Blader Ltd). The drops obtained were applied gently to plain filter paper (Whatman No 4619) and allowed to soak through, giving a spot at least $6 \mathrm{~mm}$ diameter (ensured by viewing from both sides of the paper). If this size was not obtained another drop was applied immediately before any appreciable drying occurred. Up to six spots were obtained from each patient. Similar blood spots were made on the same piece of filter paper with venous blood withdrawn by venepuncture immediately after the patients had taken their capillary samples, and the remaining venous blood was added to a fluoride tube. The filter paper spots were dried and stored at room temperature.

The reagents used in the assays were as described by Trinder $^{9}$; D-glucose $10 \mathrm{mmol} / 1(180 \mathrm{mg} / 100 \mathrm{ml})$ in saturated benzoic acid served as standard.

\section{ASSAY PROCEDURE}

Whole blood glucose was assayed as described, ${ }^{9}$ except that $500 \mu l$ of the supernatant after protein precipitation was added to $1 \mathrm{ml}$ of colour reagent. A quality-control sample was assayed in each batch.

Blood spots-Protein precipitant $(500 \mu \mathrm{l})$ was added to a series of labelled test-tubes. For each sample one $6 \mathrm{~mm}$ diameter disc (containing approximately $11 \mu \mathrm{l}$ of blood) was punched from the centre of each of two blood spots (enabling the assay to be performed in duplicate). Similar discs were punched from the plain filter paper (as blanks). Punching was performed from the reverse side of the filter paper to which the blood had been applied to ensure completeness of the sample. Each disc was then added to a test-tube, capped, mixed by inversion, and left to elute for at least one hour at room temperature. The discs were then removed with forceps and the eluate centrifuged. Aliquots of the clear supernatants $(250 \mu \mathrm{l})$ were 
transferred to clean test-tubes and $500 \mu \mathrm{l}$ of colour reagent was added. The assay was then completed as described. ${ }^{9}$

Calculation-The glucose standard used in the whole blood method was utilised for calculating the blood spot results. A correction factor $(\times 1.515)$ was applied to allow for the difference in final dilution between the two methods. With this technique blood glucose concentrations up to $27 \mathrm{mmol} / 1(486 \mathrm{mg} / 100 \mathrm{ml})$ may be measured, but concentrations up to $54 \mathrm{mmol} / \mathrm{l}(973 \mathrm{mg} / 100 \mathrm{ml})$ may be measured by diluting $125 \mu \mathrm{l}$ of the remaining eluate one in one with precipitant.

\section{Results}

Reproducibility-Reproducibility of the capillary blood spot assays was assessed within and between batches using spots prepared from two volunteers. For the within-batch assessment 10 spots from each volunteer were measured in the same batch, and for the betweenbatch assessment 10 spots from each volunteer were assayed singly in 10 individual assays over two days. A two-day period was used to avoid sample deterioration (see below). Table I gives the results.

TABLE I-Within-batch and between-batch reproducibility of capillary blood spot glucose assays ( $\mathrm{mmol} / \mathrm{l})$. (In each case $n=10$ )

\begin{tabular}{|c|c|c|c|c|}
\hline & \multicolumn{2}{|c|}{ Within-batch } & \multicolumn{2}{|c|}{ Between-batch } \\
\hline & $\operatorname{Mean} \pm \mathbf{S D}$ & $\begin{array}{l}\text { Coefficient of } \\
\text { variation }(\%)\end{array}$ & Mean \pm SD & $\begin{array}{l}\text { Coefficient of } \\
\text { variation }(\%)\end{array}$ \\
\hline $\begin{array}{l}\text { Subject } 1 \\
\text { Subject } 2\end{array}$ & $\begin{array}{l}4 \cdot 0 \pm 0.23 \\
4.7 \pm 0.25\end{array}$ & $\begin{array}{l}5 \cdot 7 \\
5 \cdot 2\end{array}$ & $\begin{array}{l}4.0 \pm 0.26 \\
5.0 \pm 0.29\end{array}$ & $\begin{array}{l}6.4 \\
5.9\end{array}$ \\
\hline
\end{tabular}

Conversion: SI to traditional units-Blood glucose: $1 \mathrm{mmol} / 1 \approx 18 \mathrm{mg} / 100 \mathrm{ml}$.

Between-batch reproducibility of the whole blood assays was assessed from the results of the quality-control sample measured on 36 occasions over four weeks. This gave a mean of $9 \cdot 2 \pm \mathrm{SD} 0.16 \mathrm{mmol} / 1$ $(166 \pm 2 \cdot 9 \mathrm{mg} / 100 \mathrm{ml})$ and coefficient of variation $1 \cdot 8 \%$.

Recovery from blood spot samples-Recovery was assessed by enriching an aliquot of each of nine venous blood samples with glucose to increase the concentration by $5 \mathrm{mmol} / 1(90 \mathrm{mg} / 100 \mathrm{ml})$. Blood spots were then prepared from the original and enriched samples and both assayed in the same batch. Mean recovery was $97 \pm$ SE of mean $2 \cdot 8 \%$ and ranged from $80 \%$ to $104 \%$.

Comparison of results-Table II gives the results of measurements on whole venous blood and capillary blood spot samples taken from fasting and non-fasting patients and assayed in duplicate on the day of collection. The differences were not significant (paired $t$ test).

Stability of capillary blood spot glucose values-Fifteen capillary blood spot samples were assayed in duplicate on the day of collection and after four and eight days. Changes in glucose concentrations were in proportion to the initial value, so the results were expressed as percentages of the initial value. There was no significant change in concentrations over four days $(92.9 \pm \mathrm{SE}$ of mean $3.5 \%$; Student's $t$ test: $\mathrm{P}>0.05)$, but after eight days there was a definite fall $(86.6 \pm$ $5.4 \% ; \mathrm{P}<0.05)$. Impregnating the filter papers with sodium fluoride, benzoic acid, and boric acid did not improve the stability of glucose in the samples.

TABLE II-Comparison of whole blood and capillary blood spot glucose (mmol/l) assayed on day of collection

\begin{tabular}{|c|c|c|c|c|c|c|}
\hline & \multicolumn{3}{|c|}{ Fasting } & \multicolumn{3}{|c|}{ Non-fasting } \\
\hline & No & Mean & $\begin{array}{c}\text { Mean \% } \\
\text { of venous } \\
\text { blood } \\
\text { value ( } \pm \\
\text { SE of } \\
\text { mean) }\end{array}$ & No & Mean & $\begin{array}{c}\text { Mean \% } \\
\text { of venous } \\
\text { blood } \\
\text { value ( } t \\
\text { SE of } \\
\text { mean) }\end{array}$ \\
\hline $\begin{array}{l}\text { Whole } \\
\text { venous } \\
\text { blood }\end{array}$ & 15 & $6 \cdot 2$ & 100 & 10 & $6 \cdot 4$ & 100 \\
\hline $\begin{array}{l}\text { blood } \\
\text { spot }\end{array}$ & 15 & $6 \cdot 7$ & $\begin{array}{r}107 \cdot 4 \\
( \pm 6 \cdot 1)\end{array}$ & 10 & $6 \cdot 6$ & $\begin{array}{c}102 \cdot 9 \\
( \pm 4 \cdot 7)\end{array}$ \\
\hline
\end{tabular}

Conversion: SI to traditional units-Blood glucose: $1 \mathrm{mmol} / 1 \approx 18 \mathrm{mg} / 100 \mathrm{ml}$.

\section{Discussion}

Measurements on capillary blood eluted from blood spots on filter paper are widely used for investigations on infants, particularly in screening for phenylketonuria and hypothyroidism. Variation in the size of the punched spot is a source of lack of precision; this step has been reported to have a coefficient of variation of $3 \%,^{10}$ and our experience confirms this. The packed cell volume of the samples might also be expected to affect the spreading characteristics of the blood spots, but this effect appears to be minimal unless the patient is severely anaemic. ${ }^{10}$ In this study, on patients who were not anaemic, the between-batch coefficient of variation of capillary blood spots was about $6 \%$.

The problem of long-term stability of the glucose in blood spots has yet to be overcome. Thus plain filter-paper blood spots showed a definite fall in glucose after eight days' storage at room temperature. Provided the samples were assayed within four days from the time of sampling, however, the mean glucose loss was less than $10 \%$ and the result would thus still be clinically useful. Impregnating the filter paper with boric acid has been reported to preserve the glucose for up to one month, ${ }^{7}$ but this was not confirmed by others ${ }^{8}$ or by ourselves. Like Sönksen et $a l^{4}$ and Walford $e t a l^{5}$ we found that most patients encountered no serious difficulty in providing capillary blood samples. We think that the capillary blood spot method may have advantages over the methods reported in their papers. Firstly, the results are based on laboratory determinations and there is therefore no need for regular checks on the calibration of the meters used by the patients; and, secondly, these meters (and the testing strips) are still fairly expensive. One advantage of the other approach, however, is that the immediate availability of results allows the patients to adjust their own insulin dose. Whichever method is adopted by diabetic clinics it will probably result in improved diabetic control, particularly of insulindependent diabetes.

\section{References}

${ }^{1}$ Cahill, G F, jun, Etzwiler, D D, and Freinkel, N, New England fournal of Medicine, 1976, 294, 1004

2 Alberti, K G G M, and Nattrass, $M$, in Advanced Medicine, ed G M Besser, vol 13, p 173. London, Pitman Medical, 1977.

3 Koenig, R J, et al, New England fournal of Medicine, 1976, 295, 417.

Sönksen, P H, Judd, S L, and Lowy, C, Lancet, 1978, 1, 729.

5 Walford, S, et al, Lancet, 1978, 1, 732.

${ }^{6}$ Knight, R K, and Keen, H, British Medical fournal, 1961, 1, 1168.

${ }^{7}$ Hochella, N J, and Hill, J B, in Automation in Analytical Chemistry. Technicon Symposia, ed I N B Scora et al, p 3. White Plains, N Y, Mediad, 1967.

${ }^{8}$ Seiter, C W, Hill, H D, and Summer, G K, Clinical Chemistry, 1973, 19, 1296.

9 Trinder, P, Annals of Clinical Biochemistry, 1969, 6, 24.

${ }^{10}$ Hill, J B, and Palmer, P, Clinical Chemistry, 1969, 15, 381.

\section{(Accepted 16 fune 1978)}

\section{$\varnothing_{\text {Correction }}$}

Oxamniquine for treating Schistosoma mansoni infection in Sudan

We regret that an error occurred in this article by $\mathrm{Dr} A \mathrm{H} \mathrm{S}$ Omer (15 July, p 163). The second paragraph on $p 164$ should have read: "Of the biochemical values only serum alanine transaminase (SGPT) concentrations were significantly raised on day $5 . .$. . There was no significant change in the serum aspartate aminotransferase (SGOT) concentrations."

ONE HUNDRED YEARS AGO In the Russian army in the neighbourhood of Constantinople, 25000 men are down with typhoid, typhus, and other diseases. Heavy rains fell last week. The heat is great, and a further increase of sickness is expected. (British Medical fournal, 1878.) 